\title{
Murabaha Perceptions of Islamic Bankers: Case of Pakistan
}

\author{
Muhammad Aqib Ali, ${ }^{1}$ Talat Hussain ${ }^{2}$ \\ ${ }^{1}$ International Islamic Finance $\mathcal{E}$ Insurance Institute (IIFII) \\ ${ }^{2}$ Institute of Islamic Banking, University of Management $\mathcal{E}$ Technology (UMT)
}

\begin{abstract}
The paper discusses Murabaha which is among the most significant financing tools in cotemporary Islamic banking practice. The research study is was carried out to assess the opinions and suggestions of Islamic bankers regarding Murabaha as a vital Islamic finance tool and to infer and deduce conclusions that have significance with reference to murabaha by assessing the viewpoints of Islamic bankers. The study attempts to discuss the key factors pertinent to Murabaha financing mechanism and is based on a survey research involving Islamic bankers serving at the five purely Islamic banks operating in Pakistan. The study would provide an insight regarding a highly vital and one of the most utilized tools of Islamic financing throughout the Islamic finance industries globally. The research study endeavors to identify the key factors that are pertinent with regards to Murabaha financing and to explore options to expunge the adverse perceptions regarding Murabaha-based products and services.
\end{abstract}

\section{Keywords}

Islamic Banking, Islamic Finance, Murabaha, Perceptions, Pakistan, Bankers

\section{Introduction}

Islamic financial and economic structure is based on the principle of social welfare that is actually derived and based upon Shariah guidelines to ensure prosperity and wellbeing in both world, this world and the hereafter. The philosophy of Islamic financial framework is greatly different from the contemporary conventional system that is based on the doctrine of capitalism and uncontrolled resource production and utilization that leads to materialism whereas Islamic economic and financial system entails risk sharing and offers Shariah compliant Islamic financial tools and arrangements like mudaraba, murabaha, musharakah, ijarah, and salam, etc. All these concepts are derived from the Islamic principles and are based on the Holy Quran and the Sunnah of the Holy Prophet (PBUH) to encourage and facilitate business and trade in the society and to ultimately bring economic progress and prosperity. This is amazing to realize the fact that Shariah sources, from the era when the idea of paper currency was not yet conceived, provided guidance on complex economic and financial matters. Apart from this, Shariah principles also give guidance on the schema of a system which

Corresponding Author: Muhammad Aqib Ali, e-mail: email_aqib@yahoo.com 
is economically just and equity-based and is founded upon the doctrine of social and economic welfare of all and not just some affluent individuals or groups. (Zaman 2013) The Islamic finance arrangements may be chiefly bifurcated into two major types: ones that are equity based or participatory means of finance such as musharakah and mudaraba, and secondly these include trade based or sale-based methods like Murabaha, salam, and istisna. Although the sale-based financing tools like murabahah, ijarah and istasna etc are not loans in actual terms, these give rise to debts being deferred payment transactions. (Usmani, Taqi 1999)

Murabaha is a specific type of sales transaction wherein the seller reveals the cost to the buyer and adds a specific mark-up to the cost to decide the selling price. As the assets and commodities are being traded in this transaction, Murabaha is and must always be considered a trade transaction and not be assumed as a form of loan. An ordinary sale in Arabic is termed as Musawamah - a bargaining exchange without expressing or referring to what is the original cost. On the other hand, in case of Murabaha, the cost is revealed to the buyer. (Usmani, 2002)

Murabaha - the most used Islamic financing tool by the Islamic banks and financial institutes around the world is a vital Islamic finance concept. However, the over reliance on murabaha has created doubts about the Shariah compliance and process of this Islamic finance method. The study focuses on the views of Islamic bankers to evaluate whether these doubts are well based or not and if these adverse views about murabaha are not held by Islamic bankers, what are the possible options which can be considered in order to dispel these negative opinions about Murabaha.

\section{Review of Related Literature}

Murabaha which is also referred to as the most used mode of Islamic financing tool is in fact a type of sales transaction having both the original cost and mark-up being expressly disclosed to the buyer. Obaidullah (2005) The financial institution in place of advancing an interest-based loan, for buying assets or goods by the customer, acquires the commodities/assets and assumes ownership for the subject assets. After having the ownership of assets, and consequently the incidental risks and rewards for these as well, the financial institution/bank makes the sale of the subject goods on a disclosed cost plus profit/mark-up to the client. The customer of the bank consents to buy these goods to complete the Murabaha transaction. The related terms and conditions in connection with the postponed payment are mutually decided by the parties to the transaction.

Murabahah originally refers to a unique type of sales transaction that entails the mention of the cost plus any profit, both being explicitly disclosed to the purchaser; the concept of Murabaha has in fact no relationship with financing in its true spirit. (Muhammad, Hezlina, \& Yusof 2011) Through the application of Murabaha as a tool of 
finance, the Islamic banks procure certain assets (as requisitioned from the customers) and offer to sell these to the customers on a cost plus an added mark-up/profit basis. The financier's cost includes all direct expenses incidental to the acquisition of assets like the invoice price, transportation and freight expenses, marine and during transit cover for insurance, taxes and other government duties, etc. The price of the Murabaha may be paid:

a. On the Spot at the time of initial sale;

b. In multiple installments;

c. In single amount (lump-sum) instantly or after a specific time period

There are several ways in which Murabaha financing is employed by Islamic banking and financial entities. Some of its utilizations as discussed by Usmani (2002) are mentioned hereunder:

\subsection{Contemporary Murabaha Application}

Murabaha can be applied quite easily to facilitate financing requirements of trade and industry both in the Short term and Long term:

2.1.1. Working Capital Financing - Working capital requirements such as acquisition of raw material for manufacturing or buying trading stock of goods can be done through Murabaha.

2.1.2. Trade Finance - Murabaha can be used for financing exports \& imports for the promotion of trade and commerce in a country.

2.1.3. Long, Medium and Short-Run Finance - Various financing horizons from short and medium to longer term needs for procurement of land, premises, building, equipments and machinery may also be formalized by employing Murabaha.

2.1.4. Consumer Finance - Financing for various consumer goods like appliances and durables etc may be offered on the basis of Murabaha (sale on installments). Murabaha may also be employed for house financing and purchase or procurement of material for construction of houses.

The issue of Murabaha dominance and over-utilization by Islamic banks and financial institutions globally was highlighted by Tarik (2004) in his research in which he termed this problem as "murabah syndrome" that refers to the domination of Islamic banks' product and services being based on chiefly Murabaha models. He also contends that because of this reason, discrepancy persists in the theory of equity-based finance and the contemporary banking and financial practices of Islamic finance entities. The 
inability to develop a uniform and homogeneous knowledge base to accommodate the beliefs and value systems of various Muslim sects and schools has also posed a great difficulty in conceiving and implementing a system of Islamic banking and finance which conforms to the standards of general banking consumers. The procedure of improvement demands the revision of figh in the direction of Ijtehad to design new guidelines that have not been pondered upon by early Islamic scholars, or to modify these rules in line with the contemporary financial and economic issues triggered by globalization (tajdeed). The requirement is to craft a sense of harmony among the fiqh and economic schools of thought keeping in view the outlook of recent socio-economic facts and circumstances. To be precise, we must be relatively more accommodating and supple while addressing the current economic landscape and financial trends which in fact call for new research in Islamic finance along-with the re-invigorating of Islamic thinking and taking into account, the Islamic scholars' viewpoint on global developments. (Ibrahim, 2006).

Most Islamic banks employ murabaha as their most preferred financing option/product which is in fact one of the least preferable alternatives of Islamic financing modes according to the majority of Islamic finance scholars around the world. In various regions and countries where Islamic banking is thriving in an impressive manner, for instance, Malaysia and some of the Middle Eastern and Gulf States, Islamic tools of finance like tawarruq and murabaha etc., are most used which reflects the lack of compliance levels as per the pure guidelines of Shariah. This is unfortunately a glaring fact that if we deeply analyze the prodcts and services of Islamic banking and financial entities, we may easily realize that Murabaha is the most employed tool of Islamic financing. According to the Islamic Banking Bulletin of SBP (March 2013), murabaha with $36 \%$ share leads the financing mix share of Islamic banks, just after diminishing musharakah which is $35.7 \%$. The financing through murabah by the IFIs (Islamic financial institutions) up to March 2013 was 90.4 billion rupees and 89.7 billion rupees from dimisnhing musahrakah was financed. Almost same or mostly similar is the scenario in other countries where Islamic banking is thriving. For reference, financing mix share of murabahah in Islamic banks and other Islamic financial institutions in Bahrain and Malaysia is over 54 percent. (A. Samad, Norman, et al. 2005), and in Sudan it is more than $43 \%$. Apart from operational issues that need attention of Islamic finance scholars and Islamic bankers towards murabaha, there is also another important matter that must be considered while analyzing the viability of murabaha as an Islamic finance tool - the issue of moral hazard. This implies that the entrepreneur/business owner i.e. the bank's client who avails financing through murabaha, can be lured to involve in moral hazard whenever the circumstances permit this to happen.

From Shariah point of view, Murabahah financing contains several types of risks which are to be anticipated and countered by the Islamic banks. These risks include, among 
others, market risk, price risk, default risk, and commodity risk. (Iqbal and Mirakhor 2007) It is not the acceptability of murabahah transactions per se but their imprudent utilization and flawed structuring, that guarantees in many instances a predetermined profit rate which is based on prevailing interest rate, that actually is creating the view that from Islamic banks interest has not been taken out but it is still in; it in fact exists in an Islamic cover (Hasan 2009). This is also noted that negative about murabaha perceptions about Mudaraba are based not on the Islamic mode itself but rather on its over - utilization by Islamic banks globally. (Alsayyed 2010) This perception is held by the critics of Islamic banking and the views of Islamic bankers are most relevant to ascertain whether the negative perceptions about murabaha have substance or not because their views are the opinions of insiders of the industry and this study aims to determine the viewpoint of these important stakeholders regarding murabaha.

\section{Problem Statement}

The use of Murabaha as an Islamic finance mode is prevalent in Pakistan and other Islamic banking industries around the world. The utilization of murabaha finance is not questionable but it is actually the over utilization of this financing method that arises reservations. By evaluating the perceptions of Islamic bankers and assessing their opinions regarding murabaha, the negative viewpoints can be obliterated to promote a better understanding of the concept and to enhance applicability of this vital Islamic financing mechanism.

\section{Research Methodology 4.1. Research Design}

The study is designed in a way to effectively gauge and evaluate the attitudes and perceptions towards murabaha to assess the perspectives of Islamic bankers. The research design comprises a structured and well organized questionnaire mostly administered or delivered personally and at few instances through mail, in cases where there were time and cost constraints. Apart from getting the questionnaires filled directly by the target audience i.e. the Islamic bankers, several informal and casual interview sessions were also conducted. The interviews were conducted to feed the answers in the questionnaire in cases where the bankers were not willing to write the answers themselves or otherwise preferred viva/ oral method over written researchtechnique. This proved quite vital for the research study because this helped the researcher to gain the subjective feedback simultaneously with the quantitative approach. Besides the blend of quantitative and qualitative data collection, the random interview sessions helped in confirming the responses given by the participants through filled questionnaires, in an effective way. The reasons for selecting the mentioned research design are many. The main reason is the nature of data to be collected. Questionnaires are considered as one of the best ways to fetch primary data and in this 
case, the data is primary - collected directly from the research participants. Apart from primary data, the nature of the research study has a rather qualitative inclination and in such cases, survey method of research is most preferable. The qualitative nature of the data is actually because of the fact that the study entails an evaluation of perceptions of Islamic bankers towards murabaha financing and in view of Hussey and Hussey (1997), questionnaires are the best method to know the perceptions and attitudes of research participants. The assessment of attitudes and behavior of respondents is actually done by seeking their opinions pertaining to the particular research issue/topic and questionnaires are an important instrument in this regard. (Ghauri and Gronhaug, 2002) The research study is carried out by conducting a resrach survey at all the five full-fledged Islamic banks operating in Pakistan. Attwergy (1998) contends that the questionnaires are not only good tools for collecting information and data but these enhance the overall reliability and validity of the data being collected as well. This is in fact a favorable consequence of a standardized data collection approach. The questionnaire was designed by taking into context the related researches such as the studies by Saeed, Shah and Shahin (2012), Dusuki (2008), Gerrard and Cunningham (1997). The detailed structure and different attributes of the questionnaire are detailed later in the research methodology segment.

\subsection{Research Questions}

The research study is based on both quantitative and qualitative approaches as both descriptive and numerical analysis results have been extracted. Firstly the descriptive statistical values are computed by carrying out various statistical tools and subsequently, the inferential statistical techniques such as the analysis of regression are employed for data analysis purposes. The study is essentially an evaluation of perceptions about murabaha financing as a vital Islamic mode of finance and hence the research questions are crafted in accordance with the nature of the research. Mentioned below are the research questions:

Research Question No.1: Whether the generally held views and opinions of Islamic bankers about murabaha based financing are favorable or adverse.

Research Question No.2: What are the key factors that lead to the positive viewpoint of murabaha by having a look at the perceived factors such as murabaha Shariah compliance, murabaha business value/facilitation, murabaha operations transparency, level of awareness and knowledge of Murabaha etc.

Research Question No.3: In order to obliterate the adverse perceptions, what options could be explored and what measures should be taken keeping in view, the critical role of murabaha finance in modern Islamic finance and Islamic banking sector.

In every research study, research questions form a vital organ of the study by 
endeavoring to quest for answers to some important phenomena or issue to help solve problems and to enhance the present body of knowledge by providing directions for future pertinent and similar research studies. Keeping in view the vitality of research questions, the above research questions were chalked out after careful analysis and consideration of previous research relevant to the research study and subsequently after a review of the literature. The answers to the above discussed research questions will be sought in the following sections of the study. The study will proceed in a logical manner by explaining the research methodology first, and then the instrument utilized for the conduct of research study will be discussed along with the sample details. Later, the analysis will be performed on the data collected. Afterwards, the chapters of results and conclusions will follow to sum up the research investigation.

\subsection{The Sample}

The survey encompasses all the pure Islamic banks that include Meezan Bank, Dubai Islamic Bank, Al-Barakah Bank, Bank Islami Pakistan and Burj Bank in the order of maximum branches in the country. The sample size comprises 100 Islamic bankers belonging to these five full-fledged Islamic banks. The logic of selection of 100 Islamic bankers is the total estimated population of banking staff serving in pure/full-fledged Islamic banks and hence keeping in view the statistical parameters, the sample size is being considered statistically suitable. The actual number of questionnaires distributed is not 100 but the researcher kept on getting the questionnaires filled irrespective of the actual number of questionnaires distributed until the sample size of 100 was reached and it was made sure that all the 100 questionnaires are complete, valid and suitable to be considered for their inclusion in the data collection process in the course of the research study. The samples were randomly selected from the customers by visiting different bank branches during business hours. To avoid sampling errors and any sort of sampling biases, the researcher varied visit timings, contacted both genders subject to their availability at the time of the visit to the banks, and avoided any kind of prejudices while collecting data like considering any characters of participants like ethnicity, social status and any type of attributes, for the judgment which could hinder the objective collection of data from the target participants. The bank branches were randomly visited in the four major cities of Pakistan including Islamabad, Karachi, Lahore and Faisalabad. In all these cities there are branches of almost all the mentioned Islamic and conventional banks which are selected for the survey study. The reason behind the selection of Islamabad is that it is the capital city of the country and hence it makes sense to choose this city and it is indeed one of the obvious choices for such kind of research study. Karachi on the other hand, is termed as the heart of Pakistan. It is the largest city in Pakistan and is the economic hub of the country having most head offices of the banks selected for the survey study. Lahore is the biggest city of the largest province of the country and has maximum number of Islamic banking branches after Karachi (State Bank of Pakistan Islamic Banking Bulletin 2013). The raison d'être of 
Faisalabad being in the survey is that it comes at number five in terms of Islamic banking branch count, after Karachi, Lahore, Islamabad and Rawalpindi respectively. Another reason fro selecting Faisalabad in the survey is the fact that it is called the Manchester of Pakistan because it is the industrial hub of the country with a powerful textile sector and a very broad Islamic banking base.

\subsection{The Instrument Employed}

As described earlier, a structured questionnaire was used for the data collection purpose from the research participants. The intention was to keep the questionnaire as easy to understand as possible for the respondents and hence this was kept in mind while designing the questionnaire. The structured questionnaire employed in the research is dissected into two broad sections. There were single line brief instructions about how to answer the entries with ease and convenience by the participants and most importantly without mistakes and errors. The questionnaire contained a total of twenty questions/items asked from the respondents. The questions were designed keeping in view the literature review and previously conducted relevant studies especially the ones conducted by Saeed, Shah and Shahin (2012) and Gerrard and Cunningham (1997). The number of questions was planned very carefully as the length and layout of the questionnaire has a close relationship with the data accuracy and reliable data collection. The same point was highlighted by Giuseppe Iarossi (2006) that the length of questionnaire has a considerable effect on accuracy of data. Before the first section in the questionnaire starts, there is a brief introduction to the survey conducted, along with an assurance that the principles and ethics of research would be followed by ensuring the anonymity and confidentiality of the respondents. The first section aims at grasping the social and demographic attributes of the participants. In this initial division of the questionnaire, respondents are requested to give answers to questions about their gender, age and education etc. The second more elaborate and vital segment in the context of the research problems being investigated in this study is focused on having an insight of the perspectives and opinions of participants regarding Islamic financing method under consideration i.e. murabaha. This section comprises fourteen Likert Scale (1932) statements. The Likert Scale was laid on a scale of one to five where five denotes Strongly Agree and one indicates Strongly Disagree on the scale where the questions are positively worded. Most of the statements were positively worded but there were a couple of statements that were negatively worded to assess the varying attitude and participation level of the respondents. The scale is thus reversed in case of negatively worded statements which suggests that one implies Strong Agreement whereas five signals Strong Disagreement with the given statement. 


\section{Analysis \& Results}

In the first part of this analysis section, the demographic information of the respondents, as collected in the questionnaire's first section, is presented. This information includes various personal characteristics of respondents like gender, age and academic qualification etc. In the later parts, the second section of the questionnaire is analyzed through various statistical measures including the measures of variation and inferential statistics like regression analysis.

\subsection{Demographic Analysis}

The results of the first segment of the questionnaire present the details of personal characteristics of respondents like gender, religion and age etc. Among the 100 respondents in total, $82 \%$ of the participants were male and $18 \%$ of them were female, $61 \%$ of the participants were aged below 36 years of age depicting that the majority of the participants were in the initial phases of their careers in the banking industry. This fact can also be corroborated if we assess the grade or rank of bankrs included in the research study. The findings also reflect that the majority of participants, precisely sixty percent of the participants were middle scale bankers whereas $25 \%$ of the participants were designated at higher ranks i.e. at upper scale or managerial level while the remaining $25 \%$ were junior scale Islamic bank employees in their careers' beginning phase. With reference to the participants' educational outlook, $22 \%$ of the participants were professionally qualified while merely a meager percentage of two percent of respondents hold a Doctorate degree. Majority of the respondents were the holders of a Bachelors degree; these comprised $42 \%$ of the total participants. When we evaluate the level of income for our research participants, we may analyze that most of the respondents, $36 \%$ of them, receive remunerations above PKR 25,000 in a month. Among the total of 100 respondents, only 30 respondents had an income scale above PKR 50,000 a month. There was also a little percentage of the participants who had extremely small earnings ratio i.e. below 10,000 PKR. These respondents comprised $8 \%$ whereas, there were participants who had a very high scale of income i.e., those who earned more than PKR 100,000 in a month. These respondents accounted for $9 \%$ of the total respondents. Lastly in the section of demographics, participants were inquired about religion, the findings were expected as Pakistan being a Muslim majority state, the researcher also anticipated similar results as mentioned. There was merely a single Non-Muslim from the aggregate of the hundred respondents who participated in the research survey. Now let us elucidate our analysis keeping in view the research questions designed by the researchers in the next section that deals with the opinions of participants about Murabaha.

\subsection{Regression Analysis}

To evaluate the Murabaha precepts of Islamic bankers about Murabaha-based product structures and offerings, the second part of the questionnaire was designed by the 
researcher. As we have discussed previously, 100 Islamic bankers from five purely Islamic banks were selected randomly for the survey-study. The questionnaires were mostly administered personally and some of the questionaires were also distributed among the Islamic bankers. In the questionnaire, there were a total of 14 items in the second part to collect data regarding the murabaha financing in particular. The allocation of these 14 entries in the questionnaire and the respective variables extracted from these questionnaire items is provided in the Table 1.1. The questionnaire items were comuted into five key factors for the purpose of analysis. From the total of fourteen likert-scale assertions, the five vital factors were extracted out. These were chalked-out keeping in consideration the earlier similar researches and the experience and expertise of the researcher on the subject under study i.e. financing based on Murabaha.

Table 1.1

\begin{tabular}{|c|l|c|}
\hline Serial No. & \multicolumn{1}{|c|}{ Variable } & Variable Category \\
\hline 1 & Shariah Compliance & Independent \\
2 & Transparency of Operations & Independent \\
3 & Business Value/Facilitation & Independent \\
4 & Awareness Level \& Knowledge & Independent \\
5 & Murabaha Perceptions & Dependent \\
\hline
\end{tabular}

\subsection{Descriptive Values Based on Statistical Analysis}

Table 1.2 presents the descriptive statistical results for five key factors identified above in table 1.1. The three variables i.e. level of compliance in terms of Shariah, Murabaha transparency of operations, and Murabaha business value, all have means above 3 which implies that most of the participants are indifferent or neutral with reference of these three factors. Knowledge/Awareness Level and Murabaha Perceptions factors have mean values of 3.9 and 3.7 respectively, which indicates that the participants have a very good and favorable viewpoint regarding Murabaha finance and also the respondents have reasonable knowledge about Murabaha based financing mechanisms. Normality of all these variables can be evidenced from histogram with a normal curve, value of skewness and kurtosis. The table also ratify that the normality assumption is fulfilled for all factors as all the factors have skewness values that fall between +1 and -1 .

For the purpose of generalizing, the descriptive results based on statistical analysis, Multiples OLS (Ordinary Least Squares) method of regression is adopted by including four independent factors and one dependent variable. 
Ali and Hussain

Table 1.2 Descriptive Statistical Results

\begin{tabular}{|l|c|c|c|c|c|}
\hline & $\begin{array}{c}\text { Shariah } \\
\text { Compliance }\end{array}$ & $\begin{array}{c}\text { Transparency } \\
\text { of } \\
\text { Operations }\end{array}$ & $\begin{array}{c}\text { Business } \\
\text { Value }\end{array}$ & $\begin{array}{c}\text { Awareness } \\
\text { Level \& } \\
\text { Knowledge }\end{array}$ & $\begin{array}{c}\text { Murabaha } \\
\text { Perceptions }\end{array}$ \\
\hline Median & 3.2500 & 3.3333 & 3.5000 & 4.0000 & 4.00 \\
Mean & 3.0525 & 3.1667 & 3.3300 & 3.9125 & 3.74 \\
Skewness & -.556 & -.186 & -.367 & -.841 & -.803 \\
Standard Deviation & .79720 & .78640 & .91624 & .67830 & 1.307 \\
Std. Error of Skewness & .241 & .241 & .241 & .241 & .241 \\
Std. Error of Kurtosis & .478 & .478 & .478 & .478 & .478 \\
Kurtosis & -.064 & -.532 & -.506 & 1.430 & -.678 \\
\hline
\end{tabular}

The conceived model for regression analysis is constructed hereunder:

$$
M P_{i}=b_{0}+b_{1} S C_{i}+b_{2} T_{i}+b_{3} B V_{i}+b_{4} A K_{i}+u_{i}
$$

Where

$$
\begin{aligned}
& \mathrm{MP}=\text { Murabaha Perceptions } \\
& \mathrm{TO}=\text { Transparency of Operations } \\
& \mathrm{SC}=\text { Shariah compliance } \\
& \mathrm{BV}=\text { Business Value } \& \text { Facilitation } \\
& \mathrm{AK}=\text { Awareness Level and Knowledge }
\end{aligned}
$$

Table 1.3: Analysis of Variance

\begin{tabular}{|c|l|c|c|c|c|c|}
\hline \multicolumn{2}{|c|}{ Model } & $\begin{array}{c}\text { Sum of } \\
\text { Squares }\end{array}$ & df & Mean Square & F & Sig. \\
\hline 1 & Regression & 91.711 & 4 & 22.928 & 28.095 & $.000 \mathrm{a}$ \\
& Residual & 77.529 & 95 & .816 & & \\
& Total & 169.240 & 99 & & & \\
\hline \multicolumn{7}{|l|}{ a. Predictors: (Constant), Knowledge and awareness, Shariah Compliance, } \\
Business support and value, Operations and Transparency \\
b. Dependent Variable: Murabaha Perceptions \\
\hline
\end{tabular}

In order to proceed to the regression estimates first, we have to check whether going through the process of estimation is worthwhile as compared to checking means only or not. From table 1.3, it can be evidenced that at $5 \%$ level of significance, model is highly significant so model estimation is more appropriate than mean. For the sake of evaluating the explanatory strength of our model, the R square which is also referred to 
as coefficient of determnation, may be anlyzed from table 1.4 having the value of 0.542 . It means $54.2 \%$ variation in dependent variable may be elucidated from the pertinent independent factors included in our model. This is quite strong but may be deceptive, hence for this reason, adjusted value of $\mathrm{R}$ square is established. Our overall model is suitable and may be utilized for determining the value of coefficients.

Table 1.4: Summary of First Model

\begin{tabular}{|c|c|c|c|c|}
\hline Model & R & R Square & $\begin{array}{c}\text { R Square } \\
\text { (Adjusted) }\end{array}$ & $\begin{array}{c}\text { Standard Error } \\
\text { for Estimate }\end{array}$ \\
\hline 1 & $.736^{\mathrm{a}}$ & .542 & .523 & .903 \\
\hline \multicolumn{5}{|c|}{ a. Predictors: (Constant), Knowledge and awareness, Shariah Compliance, } \\
Business value/facilitation, Transparency of Operations \\
\hline
\end{tabular}

Table 1.5 Coefficients

\begin{tabular}{|l|l|l|l|l|l|l|l|}
\hline \multicolumn{2}{|c|}{ Model } & \multirow{2}{*}{ Sig. } & \multirow{2}{*}{$\begin{array}{l}\text { Zero- } \\
\text { order }\end{array}$} & \multicolumn{2}{|c|}{ Correlations } & \multicolumn{2}{c|}{$\begin{array}{c}\text { Statistics of } \\
\text { Collinearity }\end{array}$} \\
\cline { 6 - 9 } 1 & & Partial & Part & Tolerance & VIF \\
\hline & Constant) & .005 & & & & & \\
Shariah Compliance & .000 & .600 & .370 & .269 & .697 & 1.435 \\
Transparency of Operations & .001 & .596 & .337 & .243 & .666 & 1.501 \\
Business value & .743 & .317 & -.034 & -.023 & .750 & 1.332 \\
Awareness Level \& Knowledge & .001 & .595 & .322 & .230 & .581 & 1.722 \\
\hline
\end{tabular}

In order to verify the problem of multicollinearity, collinearity diagnostics are estimated in table 1.6. If Eigen value falls near to zero and condition index is more than 15 then the problem of multicollinearity may exist. In Table 1.6, using Eigen value, all dimensions have problem of multicollinearity and using condition index dimension 5 may have the severe problem of multicollinearity and dimension 2 to 4 have a minor problem of multicollinearity.

Table 1.6: Diagnostics of Collinearity

\begin{tabular}{|c|c|c|c|}
\hline Model & Dimension & Eigenvalue & Condition Index \\
\hline 1 & 1 & 4.877 & 1.000 \\
& 2 & .049 & 9.976 \\
& 3 & .033 & 12.248 \\
& 4 & .029 & 12.949 \\
& 5 & .013 & 19.667 \\
\hline
\end{tabular}


After identification of multicollinearity, there may be more than one solution. First of all factor analysis can be performed in order to combine the dimensions with high correlation to form one factor. Secondly, stepwise regression can be performed. In stepwise regression, initially variables with high correlation are dropped and included one by one in order to explore the model with high statistical significance and explanatory power. In order to remove the problem of multicollinearity, stepwise regression is performed and results are displayed in Table 1.7. All the three models are statistically significant which means bank employees have a favorable perception of Murabaha. Although all models are significant but model 3 is preferred because it considers a majority of the variables and excludes only one variable that is business support and value.

Table 1.7: ANOVA

\begin{tabular}{|ll|c|l|c|c|c|}
\hline & Model & Sum of Squares & df & Mean Square & F & Sig. \\
\hline 1 & Regression & 60.836 & 1 & 60.836 & 54.997 & $.000 \mathrm{a}$ \\
& Residual & 108.404 & 98 & 1.106 & & \\
& Total & 169.240 & 99 & & & \\
2 & Regression & 82.021 & 2 & 41.011 & 45.610 & $.000 \mathrm{~b}$ \\
& Residual & 87.219 & 97 & .899 & & \\
& Total & 169.240 & 99 & & & \\
3 & Regression & 91.623 & 3 & 30.541 & 37.774 & $.000 \mathrm{c}$ \\
& Residual & 77.617 & 96 & .809 & & \\
& Total & 169.240 & 99 & & & \\
\hline
\end{tabular}

As far as explanatory power of models is concerned, $R$ square is increased as compared to initial regression with problems of multicollinearity. But after removal of multicollinearity problem in table 1.8 , model 3 has more explanatory power as compared to model 1 and Model 2. It means model 3 has a good fit.

Table 1.8: Summary of All Models

\begin{tabular}{|c|c|c|c|c|}
\hline Model & R & R Square & $\begin{array}{c}\text { Adjusted } \\
\text { R Square }\end{array}$ & $\begin{array}{c}\text { Std. Error of } \\
\text { the Estimate }\end{array}$ \\
\hline 1 & $.600 \mathrm{a}$ & .359 & .353 & 1.052 \\
2 & $.696 \mathrm{~b}$ & .485 & .474 & .948 \\
3 & $.736 \mathrm{c}$ & .542 & .527 & .899 \\
\hline
\end{tabular}


Table 1.9: Coefficients

\begin{tabular}{|c|c|c|c|c|c|c|}
\hline \multirow{2}{*}{\multicolumn{2}{|c|}{ Model }} & \multicolumn{2}{|c|}{$\begin{array}{l}\text { Unstandardizec } \\
\text { Coefficients }\end{array}$} & \multirow{2}{*}{\begin{tabular}{|c|}
$\begin{array}{c}\text { Standardized } \\
\text { Coefficients }\end{array}$ \\
Beta
\end{tabular}} & \multirow[b]{2}{*}{$\mathrm{t}$} & \multirow[b]{2}{*}{ Sig. } \\
\hline & & B & $\begin{array}{l}\text { Std. } \\
\text { Error }\end{array}$ & & & \\
\hline \multirow[t]{2}{*}{1} & (Constant) & .738 & .418 & & 1.765 & .081 \\
\hline & Shariah Compliance & .983 & .133 & .600 & 7.416 & .000 \\
\hline \multirow[t]{3}{*}{2} & (Constant) & -.423 & .447 & & -.947 & .346 \\
\hline & Shariah Compliance & .670 & .136 & .409 & 4.936 & .000 \\
\hline & Operations and Transparency & .668 & .138 & .402 & 4.854 & .000 \\
\hline \multirow[t]{4}{*}{3} & (Constant) & $-1.61 \mathrm{\theta}$ & .547 & & -2.954 & .004 \\
\hline & Shariah Compliance & .526 & .135 & .321 & 3.881 & .000 \\
\hline & Transparency of Operations & .491 & .140 & .295 & 3.495 & .001 \\
\hline & Awareness Level and Knowledge & .562 & .163 & .291 & 3.446 & .001 \\
\hline
\end{tabular}

So on the basis of Table 1.9, our final regression model with three independent variables is as follows:

$$
\begin{aligned}
& \mathrm{MP}_{\mathrm{i}}=\mathrm{b}_{0}+\mathrm{b}_{1} \mathrm{SC}_{\mathrm{i}}+\mathrm{b}_{2} \mathrm{TO}_{\mathrm{i}}+\mathrm{b}_{3} \mathrm{AK}_{\mathrm{i}} \\
& \mathrm{MP}=-1.62+0.53 \mathrm{SC}_{\mathrm{i}}+0.49 \mathrm{TO}_{\mathrm{i}}+0.56 \mathrm{AK}_{\mathrm{i}}
\end{aligned}
$$

From the given equation of regression, it can be deduced that compliance level in terms of Shariah has favorable effect on the Islamic bankers' perceptions about Murabaha. It also indicates that with an increase in the a degree of the level of Sharia Compliance by a single unit positive, Murabahah perceptions will be enhanced by $53 \%$. Correspondingly if the Awareness Level or knowledge about murabaha and operational transparency levels of Islamic banks are enhanced by one unit, this will eventually also enhance the scale of Murabaha opinions positively by $56 \%$ \& $49 \%$ correspondingly.

\section{Conclusion}

From the scrutiny and appraisal of findings of the study, this is well established that perceptions and opinion of Islamic bankers about Murabaha are by and large very positive. This finding also provides the response of the first research question we devised in the methodology section about Murabaha perceptions. The answer to the first research question is further ratified by the pertinent statistical values, for instance a relatively higher mean value of 3.74 extracted from respondents, to an item in the 
later segment of our research questionnaire, which was about the overall impression regarding Murabaha based products. This questionnaire statement in the second segment was specifically designed to emphasize the research question one and asked the respondents' response about their opinion regarding Murabaha. And besides this, various informal interviews along with data collected from the structured questionnaires, also corroborate the approving response by the Islamic bankers as the respondents in the research.

With respect to the research question number two, the answer was sought by the application of inferential statistics technique. Precisely the method of step wise regression was employed and the three key factors emerged from the results as being statistically significant. The constructed research model showed that these three variables have had their favorable effect on the overall Murabaha financing opinion. The three variables identified are murabaha compliance level in Shariah perspective, transparency of operations of Murabaha transactions, and awareness level and knowledge about the Murabaha-based finance. With reference to the third research question, the last two entries in the final part of the questionnaire were designed to find out the answer to this last research question. The third research question was regarding recommendations and/or suggestions to expunge adverse opinions regarding the murabaha. The reply of the respondents about how to obliterate negative Murabaha perceptions were lucid and clear as majority of the participants were of the view that refining and modifying the modus operandi of Murabaha-based transactions and operational mechanisms related to Murabaha finance; and raising awareness levels and knowledge of stakeholders like Islamic bankers, customers etc; would certainly have a favorable impact on the perceptions and opinions with regards to Murabaha financing. Moreover, the descriptive values based on statistical analysis also ratify the views of the respondents. For reference, a very high mean value for both the above mentioned questionnaire items - precisely both mean values being greater than 4.4 while having a lower dispersion statistics (standard deviation) indicate that the Islamic bankers are firmly of the belief that both the proposed options may prove highly effective to dispel adverse opinions regarding Murabaha and they may also prove very fruitful to enhance positive perceptions about Murabaha financing.

To sum-up, we can conclude that the opinions of Islamic bankers are heavily inclined in favor of Murabaha finance and a lion's share of Islamic banking executives are of the view that if Murabaha based transactions are practiced as per Shariah guidelines in a true spirit, it will not only promote the overall Shariah compliance of Murabaha based services but also would positively contribute towards enhancing the image of Islamic banking paradigm among the stakeholders. 


\section{Research Implications and Limitations}

There will be certainly favorable implications of the study. The research survey would definitely have an impact upon the Islamic banking sector in a positive way by enhncing the stakeholders' confidence about Murabaha-based services and products by considering various factors pertinent thereto. The variables assessed will provide direction to future researchers for exploring more regarding the issue of Murabaha financing products. Apart from this the industry practitioners will be able to improve the Murabaha based products and practices as per the research results and recommendations of the research study.

The research study has some limitations in terms of participants and geographical area covered in the study. The respondents hailed from only one industry i.e. only Islamic bankers. Apart from it, the participants were from Pakistan only and in future studies; the scope may be expanded by incorporating larger stakeholders base like inclusion of both Islamic and non-Islamic banking customers, regulators, etc. The scope may also be expanded by including participants from various countries where Islamic finance paradigm is emerging or is already established to create a more holistic viewpoint regarding Murabaha financing mechanism.

\section{References}

A. Samad, N. D Gardner, \& B. J. Cook (2005). "Islamic Banking and Finance in Theory and Practice: The Experience of Malaysia and Bahrain”. American Journal of Islamic Social Sciences, Vol 22:.2, 69-86.

Alsayyed , Nidal,(2010). "The Uses and Misuses of Commodity Murabaha: Islamic Economic Perspective.” PhD Researcher Islamic Economics, The Global University In Islamic Finance (INCEIF)- Malaysia.

Attwergy, A.B. (1998), The Islamic Banking Practices: Possible Acceptance in the US as Perceived by Islamic and US/Western Bankers, University of Nova, Davie, FL.

Dusuki, A.W., (2008) "Understanding the objectives of Islamic banking: a survey of stakeholders' perspectives", International Journal of Islamic and Middle Eastern Finance and Management, Vol. 1 Iss: 2, pp.132-148.

Gerrard, P . and Cunningham , J . B . (1997) ' Islamic banking: A study in Singapore ', International Journal of Bank Marketing, Vol. 15, No. 6.

Ghauri, P.N. and Gronhaug, K. (2002), Research Methods in Business Studies: A Practical Guide, Financial Times Prentice Hall, New York, NY.

Giuseppe Iarossi (2006), The Power of Survey Design: A User's Guide for Managing Surveys, Interpreting Results, \& Influencing Respondents, The World Bank, Washington DC.

Hasan, (2009), "Commodity Murabahah remains in the lurch", by Professor Zubair Hasan, Islamic Finance (Malaysian reserve); January 2009.

Hussey, J. and Hussey, R. (1997), Business Research: A Practical Guide for Undergraduate and Postgraduate Students, MacMillan Business, Oxford.

Ibrahim, Badr El Din A., (2006),"The "missing links" between Islamic development objectives and the current practice of Islamic banking - the experience of the Sudanese Islamic banks 
(SIBs)", Humanomics, Vol. 22 Iss: 2 pp. 55 - 66.

Iqbal, Zamir and Mirakhor, Abbas (2007). An Introduction to Islamic Finance: Theory and Practices. John Wiley \& Son Pte, Ltd, Singapore, 2007.

Meezan Bank Limited, Pakistan (2013), Shariah Advisor's Report 2013.

Muhammad Pisol B Mat Isa, Yusof Ibrahim \& Hezlina Hashim (2011) "Shariah on Direct \& Indirect Cost in Murabahah", International Journal of Basic \& Applied Sciences IJBAS-IJENS Vol: 11 No: 02.

Obaidullah, M. (2005), Islamic Financial Services, Islamic Economics Research Center, King Abdul Aziz University, Jeddah.

Rifki Ismal, (2009), "Assessing Moral Hazard Problem in Murabahah Financing", Journal of Islamic Economics, Banking and Finance, Volume-5 Number-2, pp. 101- 112.

Saeed Akbar, Syed Zulfiqar Ali Shah, Shahin Kalmadi, (2012) "An investigation of user perceptions of Islamic banking practices in the United Kingdom", International Journal of Islamic and Middle Eastern Finance and Management, Vol. 5 Iss: 4, pp.353 - 370.

State Bank of Pakistan (2013), Islamic Banking Bulletin March 2013.

Tarik M. Yousef, (2004), The Murabaha Syndrome in Islamic Finance: Laws, Institutions and Politics, Edinburgh University Press, United Kingdom.

Usmani, Muhammad Imran Ashraf (2002), Guide to Islamic Banking (Meezan Bank), Darul Ishaa't. Karachi.

Usmani, Muhammad Taqi (1999), Islamic Finance, New Steps, Darul Uloom, Karachi.

Zaman, Dr. Asad, (2013), "Islamic economics and the global financial crisis", Islamic Economist, 18th July, 2013. 